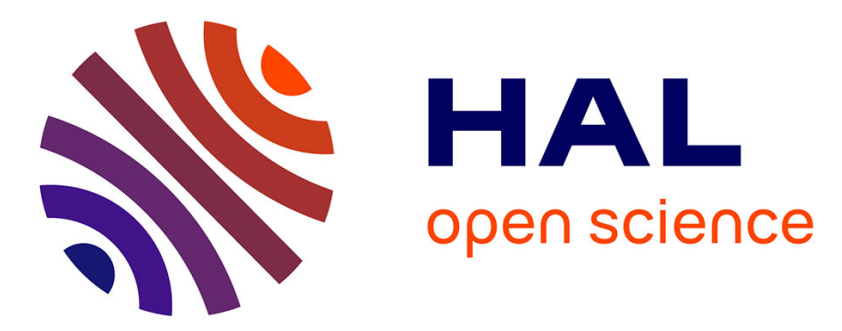

\title{
Special issue: wave electronics and applications thereof in information and telecommunication systems
}

\author{
Sergei Kulakov, A. N. Yakimov, A. Bugaev, Michiel Postema, Vitaly \\ Voloshinov
}

\section{- To cite this version:}

Sergei Kulakov, A. N. Yakimov, A. Bugaev, Michiel Postema, Vitaly Voloshinov. Special issue: wave electronics and applications thereof in information and telecommunication systems. Applied Acoustics, 2016, 112, pp.216. 10.1016/j.apacoust.2016.06.017 . hal-03192852

\section{HAL Id: hal-03192852 \\ https://hal.science/hal-03192852}

Submitted on 11 Apr 2021

HAL is a multi-disciplinary open access archive for the deposit and dissemination of scientific research documents, whether they are published or not. The documents may come from teaching and research institutions in France or abroad, or from public or private research centers.
L'archive ouverte pluridisciplinaire HAL, est destinée au dépôt et à la diffusion de documents scientifiques de niveau recherche, publiés ou non, émanant des établissements d'enseignement et de recherche français ou étrangers, des laboratoires publics ou privés.

\section{(이) $\$$}

Distributed under a Creative Commons Attribution - NonCommercial - NoDerivatives| 4.0 
Preface

\section{Special issue: Wave electronics and applications thereof in information and telecommunication systems}

From the 1st to the 5th of June, 2015, the XVIII International Conference for Young Researchers: Wave Electronics and its Applications in the Information and Telecommunication Systems took place. The conference was held on the Mikhail Sholokhov, an inland waterways passenger ship built in 1985, whilst sailing from St. Petersburg to Kizhi, Petrozavodsk, Valaam, and back to St. Petersburg.

The conference was held under the umbrella of the symposium Modern Information Society Formation: Problems, Perspectives, Innovation Approaches, which was held in parallel.

Scientists and specialists under 35 years old were invited to take part in the conference, but the organizers also encouraged leading Russian and foreign scientists, without age restrictions, to give plenary overview lectures.

Topics included, but were not limited to, nano-electronics, acoustooptics and acoustooptic methods for information processing, acoustoelectronics, signals in information and telecommunication systems, magnetostatic waves, new acoustic material properties, bulk and SAW filters, bulk and SAW oscillators and sensors, microwave oscillators, resonators, frequency synthesis, acoustooptic and acoustoelectronic methods for monitoring of the environment, and mathematical simulations of wave electronic devices.

The 34 presentations at the XVIII International Conference for Young Researchers reflected the current state of wave electronics and its applications in information and telecommunication systems, and considered to be of interest to a wide range of researchers, teachers, graduate students and professionals in the field of acoustooptics and acoustoelectronics.

Extended abstracts on all 34 presentations have been published in [1]. Furthermore, two transducer-related presentations were combined into one paper, which has been published in [2].

This special issue in Applied Acoustics highlights three superb invited papers on acoustooptics. The first authors are promising young scientists working at the most renowned and senior groups. For many readers of Applied Acoustics, this issue will be their first opportunity to get acquainted to the exciting field of acoustooptics. We trust that the three papers offered are the most promising of what this amazing field currently has to offer!

\section{References}

[1] Bestugin A, Kulakov S, Yakimov A, editors. XVIII international conference for young researchers: wave electronics and its applications in the information and telecommunication systems. St. Petersburg: Saint-Petersburg State University of Aerospace Instrumentation; 2015 [ISBN 978-5-8088-1000-6].

[2] Yddal T, Gilja OH, Cochran S, Postema M, Kotopoulis S. Glass-windowed ultrasound transducers. Ultrasonics 2016;68:108-19.

Sergei V. Kulakov

A.N. Yakimov

A. Bugaev

Saint-Petersburg State University of Aerospace Instrumentation, 67 Bolshaya Morskaya ulitsa, 190000 St. Petersburg, Russian Federation

Michiel Postema

Institute of Fundamental Technological Research, Polish Academy of Sciences, ulica Adolfa Pawińskiego 5 B, 02-106 Warszawa, Poland

School of Electrical and Information Engineering, Chamber of Mines Building, University of the Witwatersrand, 1 Jan Smuts Avenue, Braamfontein, Johannesburg 2050, South Africa

Department of Physics and Technology, University of Bergen, Allégaten 55, 5007 Bergen, Norway

Vitaly B. Voloshinov

Department of Physics, M.V. Lomonosov Moscow State University, 119991 Moscow, Russian Federation 